\title{
Adsorptive removal of chromium(VI) from aqueous solution unto groundnut shell
}

\author{
Jonas Bayuo $^{1} \cdot$ Kenneth Bayetimani Pelig-Ba ${ }^{1} \cdot$ Moses Abdullai Abukari $^{2}$
}

Received: 22 October 2018 / Accepted: 15 May 2019 / Published online: 23 May 2019

(c) The Author(s) 2019

\begin{abstract}
Chromium present in high levels in water poses a serious problem in many places around the world, sometimes in relation to natural sources and in other cases to anthropogenic ones. Adsorption process using natural materials is among the most effective techniques for removing many heavy metal ions from different types of water sources. In the present study, groundnut shell was used as a nonconventional adsorbent for effective removal of chromium(VI) from aqueous solutions using batch experiments. The adsorption of chromium(VI) unto groundnut shells was found to be dependent on contact time, $\mathrm{pH}$, adsorbent dose, initial concentration and temperature. The adsorption of $\mathrm{Cr}(\mathrm{VI})$ was found to be optimum at a contact time of $120 \mathrm{~min}, \mathrm{pH} 8.0$, an adsorbent dose of $2.0 \mathrm{~g} / \mathrm{L}$, initial metal ion concentration of $25 \mathrm{mg} / \mathrm{L}$ and temperature of $41.5^{\circ} \mathrm{C}$. The experimental data were analyzed using three two-parameter isotherm models. The experimental data obtained for the adsorption of chromium(VI) ion fitted well to Temkin isotherm in comparison with the other isotherm models tested.
\end{abstract}

Keywords Adsorbent · Adsorption · Chromium · Groundnut shell · Isotherm

\section{Introduction}

Chromium is a major toxic pollutant, which entered the water streams through various industrial operations. Sources of chromium contamination include disposal of chromiumcontaining wastes and releases from electroplating processes. The potential sources of chromium(VI) wastes are effluents from metallurgy, electroplating, leather tanning, textile dyeing, paint, ink and aluminum manufacturing industries (Wuana and Okieimen 2011). Chromium is a toxic contaminant, even in very low concentrations. Chromium in its hexavalent form $\mathrm{Cr}(\mathrm{VI})$ is well known due to its health-related issues in humans including carcinogenic and mutagenic risks (Igwe and Abia 2006; Park and Jung 2001). More so, chromium can lead to cancer in the lungs and digestive tract. Excessive intake of chromium by humans leads to

Jonas Bayuo

jonas87bayuo@yahoo.com

1 Department of Applied Chemistry and Biochemistry, University for Development Studies, Postal Box 24, Navrongo, Ghana

2 Department of Science and Mathematics Education, University for Development Studies, Postal Box 24, Navrongo, Ghana hepatic and renal damages, capillary damage, gastrointestinal irritation and central nervous system (Wan Ngah and Hanafiah 2008). The conventional methods for treatment of chromium(VI) wastes include precipitation, adsorption with activated carbon, ion exchange, membrane processes, oxidation and reduction (Meunier et al. 2006). However, most of these methods resulted in incomplete removal of metal ions, low selectivity, high operational cost, high consumption of reagents, energy and generation of secondary pollutants (Wu et al. 2004; Eccles 1999). Besides, it was revealed that these techniques when applied, some of them are usually incapable of meeting the discharged standards limits for heavy metals concentrations ranging between 0.1 and $3 \mathrm{mg} / \mathrm{L}$ (García-Sánchez and Álvarez-Ayuso 2002). The adsorption technique still remains the most effective and common applicable technology widely used over other techniques in global environmental protection areas (Xunjun 2015). Adsorption has distinct advantages over the conventional methods which include reusability of biomaterial, low operating cost, selectivity for specific metal, short operation time and no chemical sludge (Rahmani et al. 2009; Shah et al. 2009). Several agricultural materials have been used for the adsorption of heavy metals as reported in many studies including plants seeds (Edokpayi et al. 2015); pomegranate peels (El-Ashtoukhy et al. 2008); and orange peel (Li et al. 2008). 
Groundnut shells are carbonaceous, fibrous solid agricultural waste that encounters disposal problem but potentially suitable for making low-cost adsorbent for adsorption of heavy metals from water and wastewaters due to its high carbon content (Idris et al. 2012).

The present research was conducted to utilize groundnut shell as efficient alternative adsorbent materials to remove chromium(VI) from aqueous solution using three two-parameter isotherm models. The influence of operating conditions such as contact time, $\mathrm{pH}$, adsorbent dose, initial metal concentrations and temperature was studied.

\section{Experimental methods}

\section{Collection and preparation of the adsorbent and adsorbate}

All chemicals used for the study were of analytical reagent grade. Groundnut shells were collected from the local groundnut-processing center in Navrongo market.

The collected groundnut shells were washed repeatedly with distilled water to remove dust and insoluble impurities. The groundnut shells were then air-dried under room temperature and subsequently dried in an oven at $105^{\circ} \mathrm{C}$ for $24 \mathrm{~h}$ to constant mass. The groundnut shells were ground and sieved to an obtained particle size less than $300 \mu \mathrm{m}$. The groundnut shells were used for the experiments without any physical or chemical treatments as an adsorbent (AbdelTawwab et al. 2017; Choudhury et al. 2012).

In the preparation of the stock solution of the adsorbate, $\mathrm{Cr}(\mathrm{VI})$ procedures specified in APHA, (1989) were followed. Specifically, a known mass $(2.829 \mathrm{~g})$ of potassium dichromate $\left(\mathrm{K}_{2} \mathrm{Cr}_{2} \mathrm{O}_{7}\right)$ was dissolved in de-ionized water and diluted to the $1000 \mathrm{~mL}$ mark using de-ionized water. Working concentrations ranged from 15 to $100 \mathrm{mg} / \mathrm{L}$ were prepared from the stock solution by diluting the stock solution with de-ionized water to the required concentrations. The $\mathrm{Cr}(\mathrm{VI})$ concentration was determined spectrophotometrically (Carry $60 \mathrm{UV}-\mathrm{V}$ is spectrophotometer) by the diphenyl-carbazide method (Mahajan and Sud 2012).

\section{Characterization of the adsorbent}

The groundnut shell was characterized by using Fourier transform infrared spectrometer (Spectrum Two 94133 series) to determine the functional groups on the adsorbent. Characterization of the groundnut shell was done before and after the metal ion adsorption. Furthermore, the BET surface area and pore size distributions of the prepared adsorbent were carried out using Quantachrome analyzer.

\section{Equilibrium adsorption studies}

\section{Effect of contact time}

The investigation was done to determine the optimum time for adsorption of chromium(VI) using groundnut shell. In this study, $1.0 \mathrm{~g}$ of the adsorbent was contacted with $100 \mathrm{~mL}$ solutions of $50 \mathrm{mg} / \mathrm{L} \mathrm{Cr}(\mathrm{VI})$ ion adjusted to $\mathrm{pH} 6$. The solutions were transferred to $250-\mathrm{mL}$ conical flasks and agitated at $120 \mathrm{rpm}$ for different contact times (10-240 min). The mixture was filtered, and residual metal ions in the filtrate were analyzed using UV-Vis spectrophotometer (Carry 60).

\section{Effect of $\mathrm{pH}$}

The effect of $\mathrm{pH}$ on metal ion adsorption was carried out in $\mathrm{pH}$ range of 2 to $10 ; 100 \mathrm{~mL}$ solutions of $50 \mathrm{mg} / \mathrm{L} \mathrm{Cr}(\mathrm{VI})$ ion were transferred to $250 \mathrm{~mL}$ conical flasks agitated at $120 \mathrm{rpm}$ for $120 \mathrm{~min}$ with $1.0 \mathrm{~g}$ adsorbent. The mixture was filtered and the filtrate analyzed for residual metal ion using UV-Vis spectrophotometer (Carry 60).

\section{Effect of adsorbent dosage}

The effect of the amount of groundnut shell used was investigated by equilibrating $100 \mathrm{~mL}$ solutions containing $50 \mathrm{mg} / \mathrm{L}$ of $\mathrm{Cr}(\mathrm{VI})$ ion with different masses of the adsorbent $(0.5-2.5 \mathrm{~g})$ agitated at $120 \mathrm{rpm}$ for $120 \mathrm{~min}$. The mixture was filtered, and the residual metal ion in the filtrate was analyzed using UV-Vis spectrophotometer (Carry 60).

\section{Effect of initial metal concentration}

The adsorption of chromium was carried out at different initial $\mathrm{Cr}(\mathrm{VI})$ ion concentrations ranging from 15 to $100 \mathrm{mg} / \mathrm{L}$. Hundred milliliters of separate concentrations of metal ion was adjusted to optimized $\mathrm{pH}$ and taken into $250-\mathrm{mL}$ conical flasks containing maximum adsorbent dose. The solutions were agitated at a fixed stirring speed of $120 \mathrm{rpm}$ for a predetermined contact time of $120 \mathrm{~min}$. The mixture was filtered and filtrate analyzed for residual metal ions.

\section{Effect of temperature}

The effect of temperature was performed at five different temperatures ranging from 25 to $65^{\circ} \mathrm{C}$ in a thermostatic shaker machine while keeping all other parameters constant (optimum contact time, $\mathrm{pH}$, adsorbent dose, and initial concentration). The adsorbent-adsorbate solutions were agitated with a fixed speed of $120 \mathrm{rpm}$, and the constancy of the temperature was 
maintained with an accuracy of $\pm 0.5^{\circ} \mathrm{C}$. The mixture was filtered and filtrate analyzed for the residual metal ion.

The amount of adsorbate adsorbed at equilibrium, at a particular time and removal efficiency, was calculated using Eqs. (1-3).

The amount of adsorbate adsorbed at equilibrium $\left(\mathrm{q}_{\mathrm{e}}\right)$,

$q_{\mathrm{e}}=\frac{C_{0}-C_{\mathrm{e}}}{m} \times V$

The amount of adsorbate adsorbed at a particular time $t\left(q_{t}\right)$,

$q_{t}=\frac{C_{0}-C_{t}}{m} \times V$

Removal efficiency (RE),

$\mathrm{RE}=\frac{\left(C_{0}-C_{\mathrm{e}}\right)}{C_{0}} \times 100$

where $q_{\mathrm{e}}$ represents the equilibrium mass of the adsorbed substance per unit mass of adsorbent, $q_{t}$ is the amount of metal ion adsorbed at time $t, C_{0}$ is the initial metal ion concentration $(\mathrm{mg} / \mathrm{L}), C_{\mathrm{e}}$ is the equilibrium metal ion concentration $(\mathrm{mg} / \mathrm{L}), C_{t}$ is the metal ion concentration $(\mathrm{mg} / \mathrm{L})$ at time $t, V$ is the volume of solution $(\mathrm{mL})$ and $m$ is the mass of the adsorbent $(g)$.

\section{Results and discussion}

\section{Characterization of groundnut shell}

The FTIR spectra of groundnut shell before and after adsorption of $\mathrm{Cr}(\mathrm{VI})$ are shown in Fig. 1a, b, respectively. From Fig. 1a, the broad peak at $3322 \mathrm{~cm}^{-1}$ is an indicator of $-\mathrm{OH}$ and $-\mathrm{NH}$ groups. The stretching of the $-\mathrm{OH}$ groups bound to methyl radicals presented a signal between 2921 and $2169 \mathrm{~cm}^{-1}$. The peaks located at 1728 and $1629 \mathrm{~cm}^{-1}$ are characteristics of carbonyl group stretching from aldehydes and ketones. The peaks at $1509 \mathrm{~cm}^{-1}$ are associated with the stretching in aromatic rings. The peaks observed at 1024 and $913 \mathrm{~cm}^{-1}$ are due to $\mathrm{C}-\mathrm{O}$ and $\mathrm{C}-\mathrm{H}$ bonds, respectively. The phenol $(\mathrm{OH})$, amine $(\mathrm{NH})$, carbonyl $(\mathrm{C}=\mathrm{O})$ and carboxylic $(\mathrm{COOH})$ groups are important sorption sites
Fig. 1 FTIR spectra of groundnut shell before (a) and after (b) adsorption of $\mathrm{Cr}(\mathrm{VI})$ ion

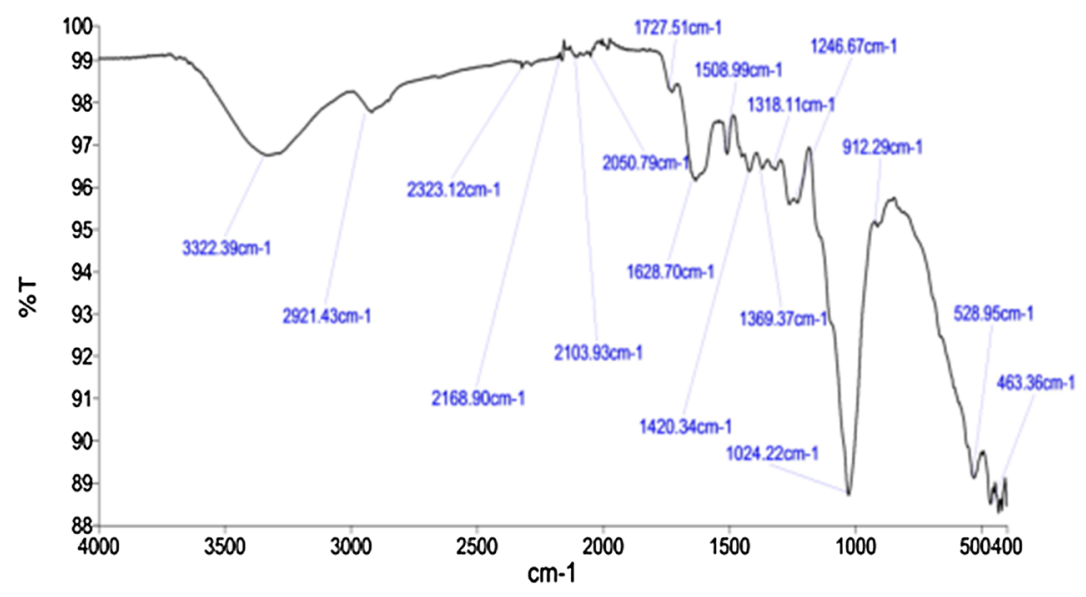

(a)

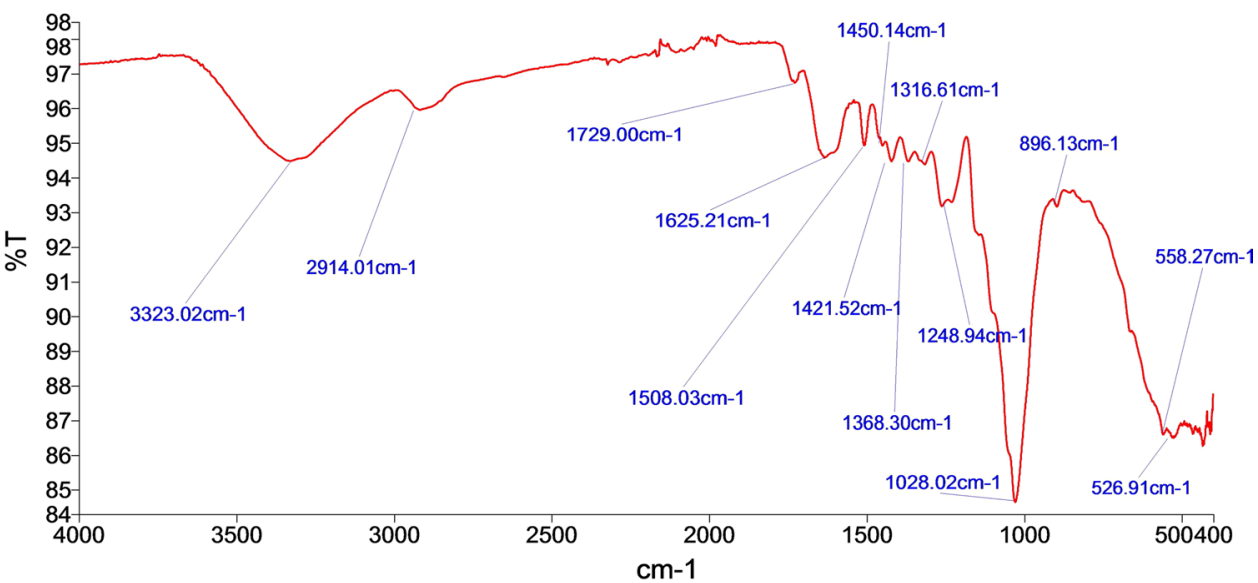

(b) 
(Qaiser et al. 2009). The presence of -OH group, coupled to carbonyl group, confirms the presence of carboxylic acid groups in the biosorbent (Chigondo and Nyamunda 2013). After the adsorption of $\mathrm{Cr}(\mathrm{VI})$, it was observed that there was broadening of $\mathrm{OH}$ peak at $3322 \mathrm{~cm}^{-1}$ and $-\mathrm{C}-\mathrm{O}$ groups at $1024 \mathrm{~cm}^{-1}$ (Fig. 1b). The broadening of $-\mathrm{OH}$ and $-\mathrm{C}-\mathrm{O}$ groups indicated the participation of $-\mathrm{OH}$ and $-\mathrm{C}-\mathrm{O}$ groups in the adsorption of chromium(VI) ion. Similar spectra were obtained for bio sorption studies of metal ions using baobab fruit shells biomass (Onundi et al. 2010).

The BET surface area and pore size distributions of the prepared adsorbent before and after treatment with $\mathrm{Cr}(\mathrm{VI})$ were determined. The BET surface area of the prepared raw adsorbent without treating it with $\mathrm{Cr}(\mathrm{VI})$ was $32.96 \mathrm{~m}^{2} / \mathrm{g}$ in comparison with activated carbon $\left(89.74 \mathrm{~m}^{2} / \mathrm{g}\right)$ reported by Yusuff (2018). However, it was found that the surface area $\left(2.48 \mathrm{~m}^{2} / \mathrm{g}\right)$ of the groundnut shell loaded with $\mathrm{Cr}(\mathrm{VI})$ ions decreased largely. More so, there was a significant decrease in the total pore volume of the adsorbent after the adsorption of $\mathrm{Cr}(\mathrm{VI})$ onto its surface. The total pore volume of the adsorbent was observed to decrease from 0.017630 to $0.00012 \mathrm{~cm}^{3} / \mathrm{g}$ after the uptake of $\mathrm{Cr}(\mathrm{VI})$ ions onto its surface. This observation could be due to aggregation of adsorption sites implying the complete loading of $\mathrm{Cr}(\mathrm{VI})$ ions onto the surface of groundnut sample used as an adsorbent (Lim and Lee 2015).

\section{Equilibrium studies on adsorption of $\mathrm{Cr}(\mathrm{VI})$}

\section{Effect of contact time}

As can be seen from Fig. 2, the adsorption process took place in two stages. The first stage was rapid, where chromium(VI) removal efficiency (Fig. 2a) and adsorption capacity (Fig. 2b) were $72 \%$ and $3.60 \mathrm{mg} / \mathrm{g}$, respectively, within the first $20 \mathrm{~min}$. The second stage represented a slower progressive adsorption process. After the first $20 \mathrm{~min}$, a gradual increase was observed and finally levels off after some $120 \mathrm{~min}$. At the $120 \mathrm{~min}$, there was no further increase or decrease in the adsorption process, which is indicative of equilibration due to saturation of adsorption sites. Rapid adsorption of metal ions during the initial stages was due to the large initial concentration gradient between the adsorbate in solution and the number of available vacant sites on the adsorbent surface (Chigondo and Nyamunda 2013). Hence, the maximum uptake of chromium(VI) was at 120 min with removal efficiency of $81.6 \%$ and adsorption capacity of $4.08 \mathrm{mg} / \mathrm{g}$.

\section{Effect of $\mathrm{pH}$}

From Fig. 3, the removal efficiency (Fig. 3a) and adsorption capacity (Fig. 3b) of $\mathrm{Cr}(\mathrm{VI})$ ion increased with an increase in $\mathrm{pH}$ attaining a maximum at $\mathrm{pH}$ 8.0. There was a rapid increase in removal efficiency and adsorption capacity when the $\mathrm{pH}$ was increased from 2.0 to 4.0 and later decreased at pH 6.0. A sharp increase was observed after $\mathrm{pH}$ of 6.0 and levels off after $\mathrm{pH}$ of 8.0. At $\mathrm{pH} 8.0$, the groundnut shells were able to give chromium(VI) removal efficiency and adsorption capacity of $59.2 \%$ and $2.96 \mathrm{mg} / \mathrm{g}$, respectively. The increase in metal adsorption with an increase in $\mathrm{pH}$ is due to a decrease in competition between hydrogen ions and metal ion for the surface sites. At lower $\mathrm{pH}$, the surface of the adsorbent is surrounded by hydronium ions $\left(\mathrm{H}^{+}\right)$, thereby blocking metal ions from binding sites on the adsorbent. At $\mathrm{pH}$ of 8.0, there was maximum adsorption of $\mathrm{Cr}(\mathrm{VI})$ ion and

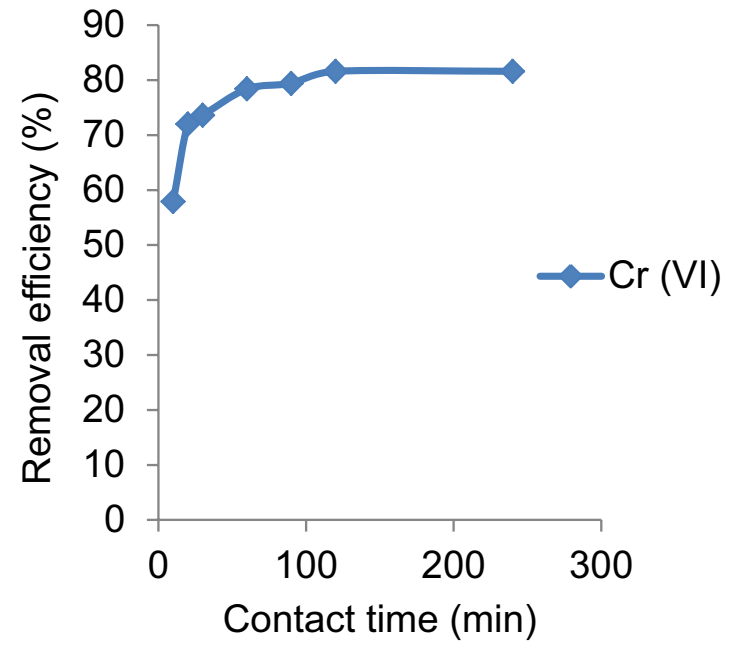

(a)

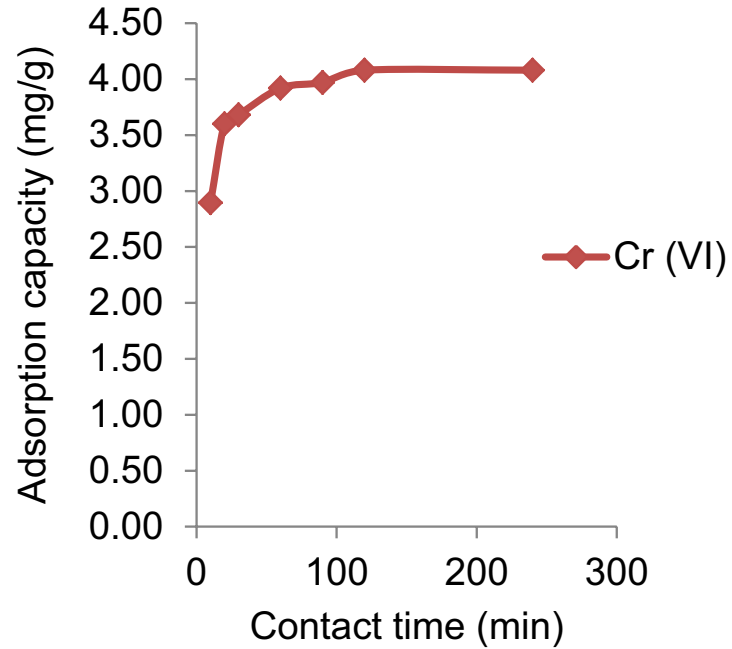

(b)

Fig. 2 Effect of contact time on the adsorption of $\mathrm{Cr}(\mathrm{VI})$ ion 


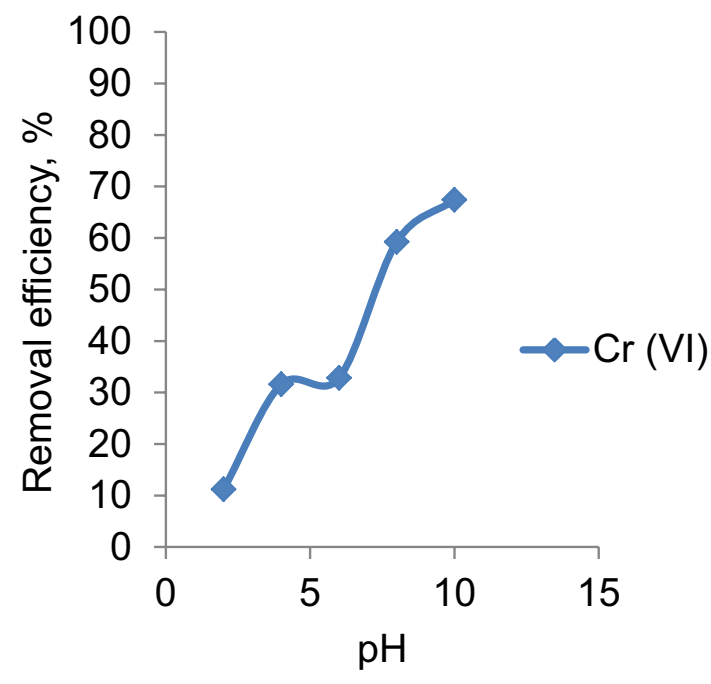

(a)

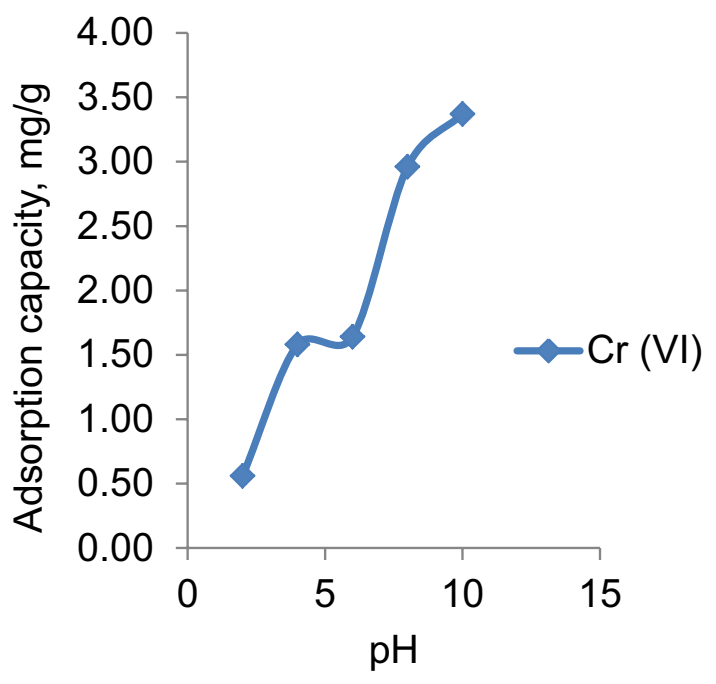

(b)

Fig. 3 Effect of $\mathrm{pH}$ on the adsorption of $\mathrm{Cr}(\mathrm{VI})$ ion

this is due to the fact that metal sorption tends to increase significantly by increasing the solution $\mathrm{pH}$ above $\mathrm{pH}_{z p c}$ of the adsorbent (Krika et al. 2016). The $\mathrm{pH}_{z p c}$ value of the groundnut shell was found to be 5.5, which is less than the maximum $\mathrm{pH}$ (8.0) obtained for the adsorption of $\mathrm{Cr}(\mathrm{VI})$ ion.

\section{Effect of adsorbent dose}

Figure 4 shows that the adsorption of chromium(VI) increased rapidly when the adsorbent dose was increased from 0.5 to $2.0 \mathrm{~g} / \mathrm{L}$ and remain constant after an adsorbent dose of $2.0 \mathrm{~g} / \mathrm{L}$. The removal efficiency (Fig. 4a) of chromium(VI) was observed to increase from 56.6 to $87.6 \%$ when the dose was increased from 0.5 to $2.0 \mathrm{~g} / \mathrm{L}$. On the contrarily, the adsorption capacity decrease from $5.66-2.19 \mathrm{mg} / \mathrm{g}$ when the adsorbent dose was increased from $0.5-2.0 \mathrm{~g} / \mathrm{L}$ as can be seen in Fig. $4 \mathrm{~b}$. The rapid increase in the removal efficiency of chromium(VI) as the amount of the adsorbent dose increases is due to the availability of more adsorption sites and greater availability of the surface area at a higher concentration of the adsorbent (Mohanty et al. 2005). The decrease in adsorption capacity (Fig. 4b) can be

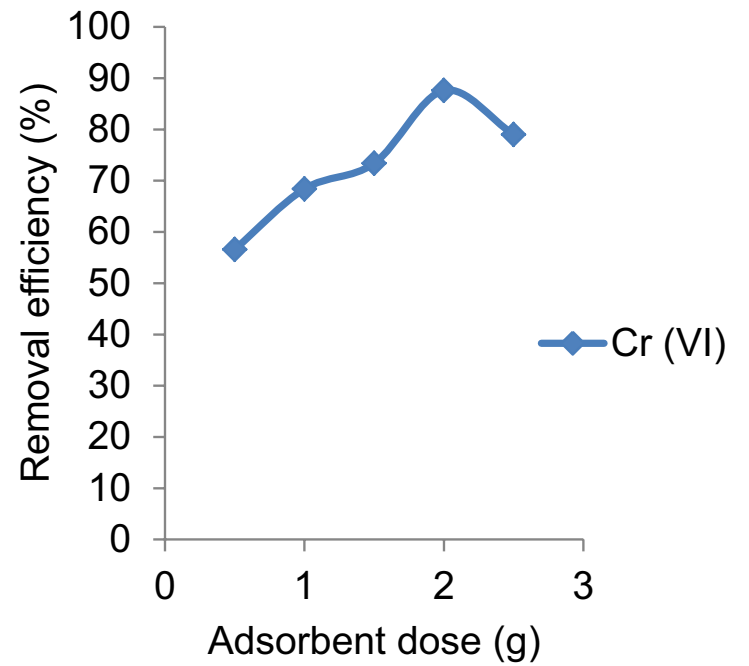

(a)

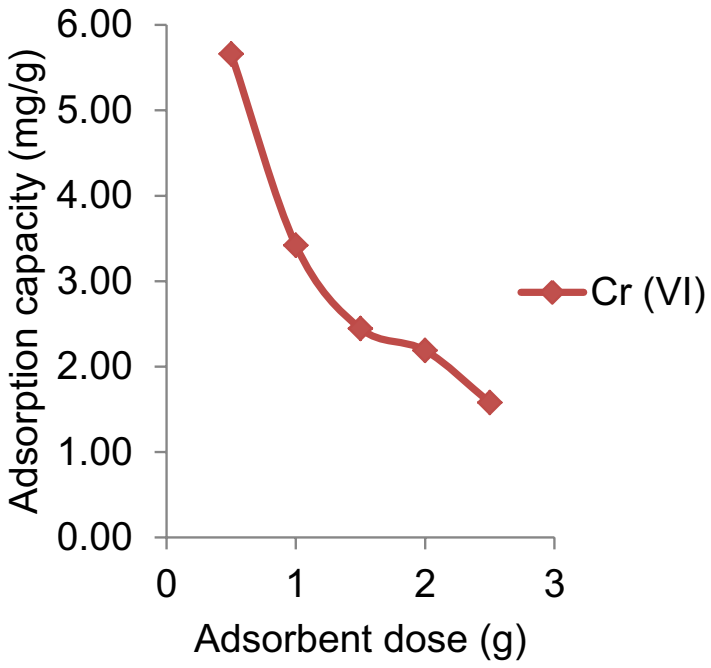

(b)

Fig. 4 Effect of adsorbent dose on the adsorption of $\mathrm{Cr}(\mathrm{VI})$ ion 


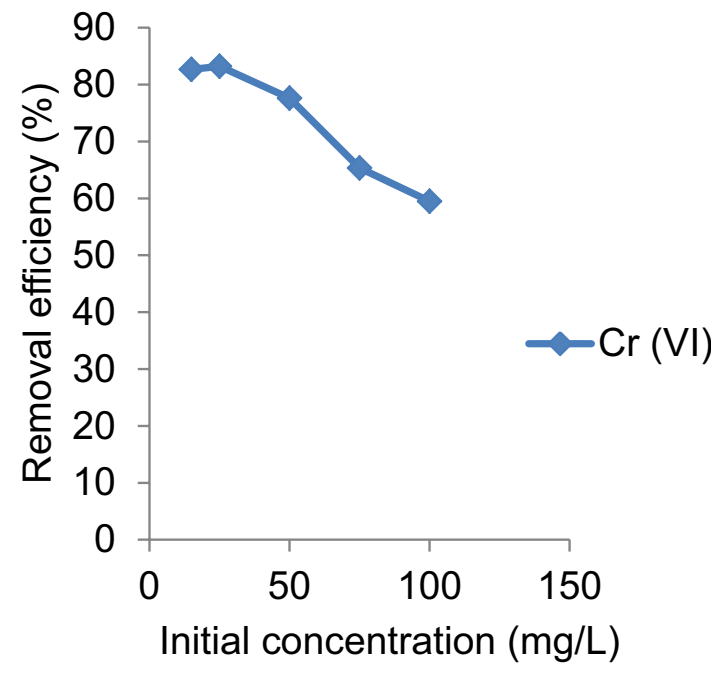

(a)

Fig. 5 Effect of initial concentration on the adsorption of $\mathrm{Cr}(\mathrm{VI})$ ion

attributed to the fact that some of the adsorption sites remain unsaturated during the adsorption process, whereas the number of available adsorption sites increases by an increase in adsorbent and this results in an increase in removal efficiency (Rengaraj et al. 2004).

\section{Effect of initial metal ion concentration}

The results presented in Fig. 5 showed that the removal efficiency (Fig. 5a) gradually decreased with increasing initial chromium(VI) ion concentration. The removal efficiency and adsorption capacity (Fig. 5b) at lower chromium(VI) concentration $(15 \mathrm{mg} / \mathrm{L})$ were found to be $82.7 \%$ and $0.62 \mathrm{mg} / \mathrm{g}$, respectively, and at higher chromium(VI) concentration $(100 \mathrm{mg} / \mathrm{L})$, the removal efficiency and adsorption capacity were $59.5 \%$ and $2.98 \mathrm{mg} / \mathrm{g}$, respectively. However, it was observed that the adsorption capacity of $\mathrm{Cr}(\mathrm{VI})$ ion increased with an increase in initial concentration, and thereafter, it reached a constant value indicating that no more $\mathrm{Cr}(\mathrm{VI})$ was further removed from solution as shown in Fig. 5.

The removal efficiency of $\mathrm{Cr}(\mathrm{VI})$ at higher concentration levels shows a decreasing trend due to the saturation of adsorption sites (Ahmet et al. 2004), whereas, at lower concentrations, all metal ions present in solution could interact with the adsorption sites and therefore higher removal efficiency. The increased in the adsorption capacity with increasing $\mathrm{Cr}(\mathrm{VI})$ ion concentration in the test solution is due to the high probability of collision between the metal ions and groundnut shell surface. Furthermore, higher concentration levels provided a better concentration gradient, which is an important driving force that helps

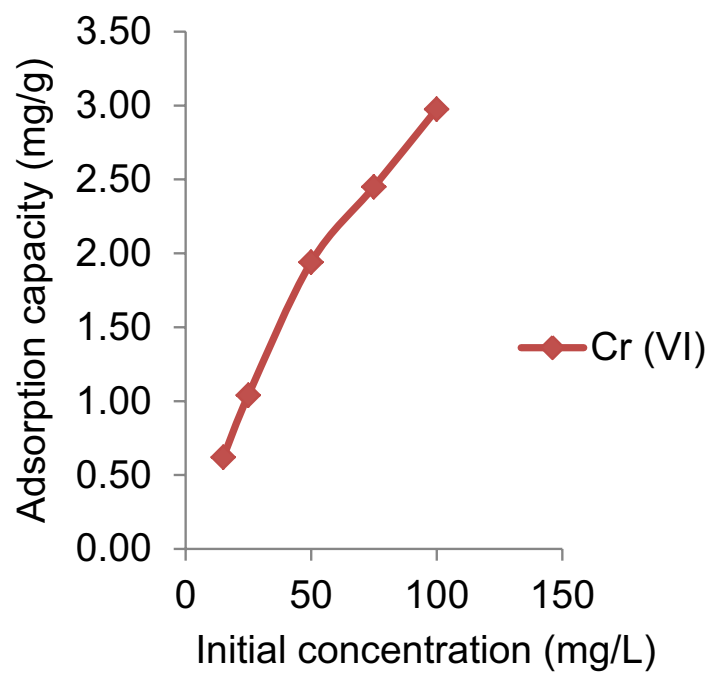

(b) overcome the mass transfer resistance of the metal ion between the liquid and solid phases (Futalan et al. 2012).

\section{Effect of temperature}

From Fig. 6, the adsorption of $\mathrm{Cr}(\mathrm{VI})$ ion increased rapidly with an initial increased in temperature and later declined with a further increase in temperature. The removal efficiency (Fig. 6a) and adsorption capacity (Fig. 6b) of chromium(VI) increased from $43.2-76.8 \%$ to $0.61-0.96 \mathrm{mg} / \mathrm{g}$, respectively, when the temperature was increased from 27.5 to $41.5{ }^{\circ} \mathrm{C}$. Further increase in temperature beyond $41.5{ }^{\circ} \mathrm{C}$ resulted in a decline in removal efficiency and adsorption capacity. At the maximum temperature $\left(41.5^{\circ} \mathrm{C}\right)$, removal efficiency and adsorption capacity were found to be $76.8 \%$ and $0.96 \mathrm{mg} / \mathrm{g}$, respectively. The removal efficiency and adsorption capacity for $\mathrm{Cr}(\mathrm{VI})$ ion increased with the increase in temperature indicating the process to be endothermic in nature (Ho 2006). This effect is characteristic of a chemical reaction or bond being involved in the adsorption process (Mohapatra et al. 2010; Aksu 2002). Alao et al. (2014), in their study on adsorption of Zn (II) ions on Carica papaya root powder, obtained similar results. They suggested that the enhancement of the adsorption capacity when the temperature is increased could be due to increased mobility and diffusion of ionic species.

\section{Adsorption isotherm studies}

The ability of groundnut shell to adsorb $\mathrm{Cr}(\mathrm{VI})$ ion from aqueous solutions was determined from the adsorption isotherms plot. The equilibrium data were applied to three two-parameter (Langmuir, Freundlich and Temkin) isotherm models, and the 


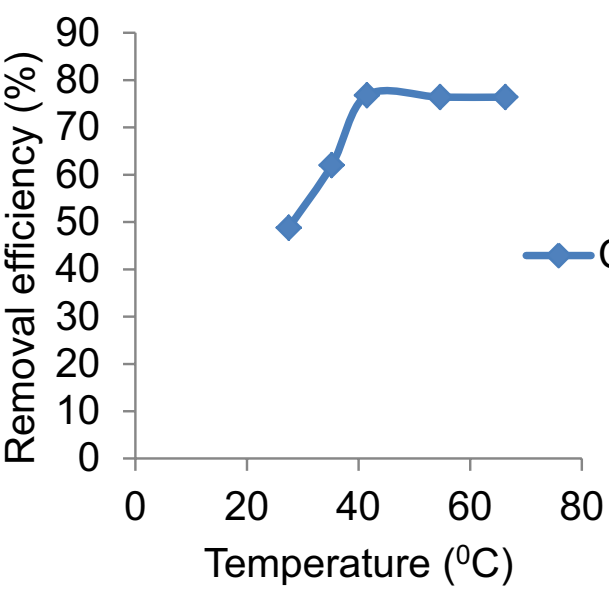

(a)

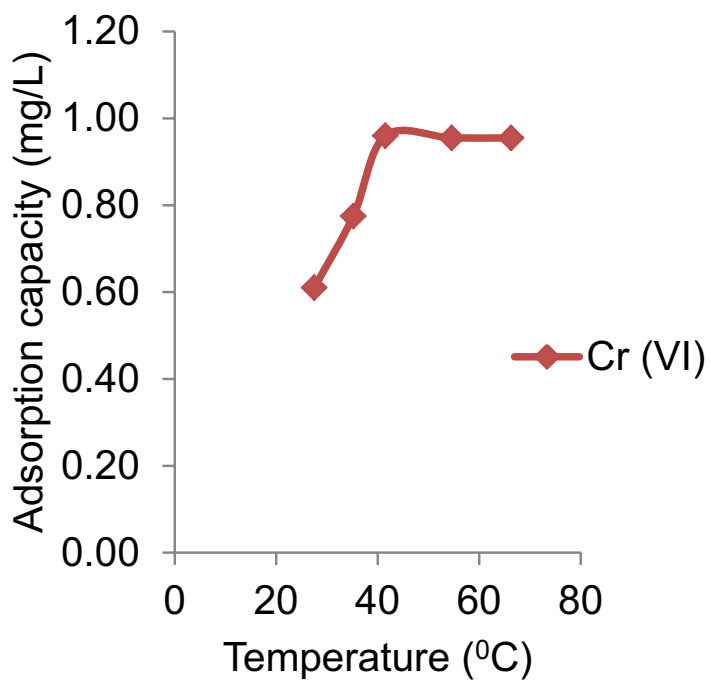

(b)

Fig. 6 Effect of temperature on the adsorption of $\mathrm{Cr}(\mathrm{VI})$ ion

results of their linear regressions were used to find the model with the best fit. The linear forms of Langmuir, Freundlich and Temkin isotherms are represented by Eqs. $(4,6,8)$.

The Langmuir adsorption isotherm model is expressed as in Eq. (4):

$\frac{C_{\mathrm{e}}}{q_{\mathrm{e}}}=\frac{1}{q_{\mathrm{m}} K_{\mathrm{L}}}+\frac{C_{\mathrm{e}}}{q_{\mathrm{m}}}$

where $C_{\mathrm{e}}$ is the concentration of chromium(VI) solution at equilibrium $(\mathrm{mg} \mathrm{P} / \mathrm{L}) ; q_{\mathrm{e}}$ is the corresponding adsorption capacity $(\mathrm{mg} \mathrm{P} / \mathrm{g})$; and $q_{\mathrm{m}}(\mathrm{mg} \mathrm{P} / \mathrm{g})$ and $K_{\mathrm{L}}(\mathrm{L} / \mathrm{mg})$ are constants which are related to adsorption capacity and energy or net enthalpy of adsorption, respectively. The constants $q_{\mathrm{m}}$ and $K_{\mathrm{L}}$ are obtained by plotting $\frac{C_{\mathrm{e}}}{q_{\mathrm{e}}}$ versus $C_{\mathrm{e}}$ (Fig. 7) with a slope of $\frac{C_{\mathrm{e}}}{q_{\mathrm{m}}}$ and intercept of $\frac{1}{q_{\mathrm{m}} K_{\mathrm{L}}}$.

The conformity of the adsorption process to the Langmuir model is usually determined using Eq. (5). The value of $R_{\mathrm{L}}$ give an idea about the shape of isotherm (Chakravarty et al. 2010).

$R_{\mathrm{L}}=\frac{1}{1+K_{\mathrm{L}} C_{0}}$

where $R_{\mathrm{L}}$ is the separation factor and $K_{\mathrm{L}}$ is the Langmuir constant $(\mathrm{L} / \mathrm{mg})$ which is related to the energy of adsorption through the Arrhenius equation. $C_{0}$ is the initial concentration of the metal ions. When $R_{\mathrm{L}}>1$, it indicates an unfavorable monolayer adsorption process, $R_{\mathrm{L}}=1$, linear, $0<R_{\mathrm{L}}<1$, favorable and $R_{\mathrm{L}}=0$, irreversible.
From Fig. 7, it is evident that the Langmuir isotherm model describes the adsorption of $\mathrm{Cr}(\mathrm{VI})$ unto groundnut shell from aqueous solution as indicated by the high correlation coefficient $\left(R^{2}\right)$ of 0.9905 . The fitness of the Langmuir model to the adsorption process connotes that the metal ion molecules from bulk solution were adsorbed on specific monolayer that is homogeneous in nature (Oluwamukomi 2009; Kumar and Sivanesan 2007). As can also be seen from Table 1 , the $R_{\mathrm{L}}$ value lies between 0 and 1 which confirms the adsorption processes to be favorable under the studied conditions. The monolayer adsorption capacity $\left(q_{\mathrm{m}}\right)$ value was found to be $3.792 \mathrm{mg} / \mathrm{g}$ indicating high adsorption capacity of groundnut shell. The value of $K_{\mathrm{L}}(0.083 \mathrm{~L} / \mathrm{mg})$ is relatively high which implies high surface energy in the process and consequently high bonding between the metal ion and the groundnut shell.

The Freundlich adsorption isotherm model is expressed as in Eq. (6):

$\log q_{\mathrm{e}}=\log K_{\mathrm{F}}+\frac{1}{n} \log C_{\mathrm{e}}$

where $C_{\mathrm{e}}$ is the concentration of solute in the bulk solution at equilibrium $(\mathrm{mg} / \mathrm{L}) ; q_{\mathrm{e}}$ is the corresponding adsorption capacity $(\mathrm{mg} / \mathrm{g}) ; K_{\mathrm{F}}$ is a constant indicative of the relative adsorption capacity of the adsorbent $(\mathrm{mg} / \mathrm{g})$ and $n$ is a constant indicative of the intensity of adsorption. From the plot of $\log q_{\mathrm{e}}$ versus $\log C_{\mathrm{e}}$ (Fig. 8), the constants $n$ can be obtained from the slope $\frac{1}{n}$ and $K_{\mathrm{F}}$ from the intercept $\log K_{\mathrm{F}}$. The slope ranges between 0 and 1 is a measure of adsorption intensity or surface heterogeneity, becoming more heterogeneous as its value gets closer to zero, whereas, a value of $\frac{1}{n}$ below unity implies a chemisorption process, $\frac{1}{n}$ above one

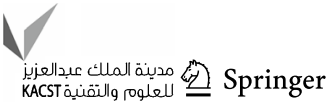


Fig. 7 Langmuir adsorption isotherm plot of $\mathrm{Cr}(\mathrm{VI})$ ion

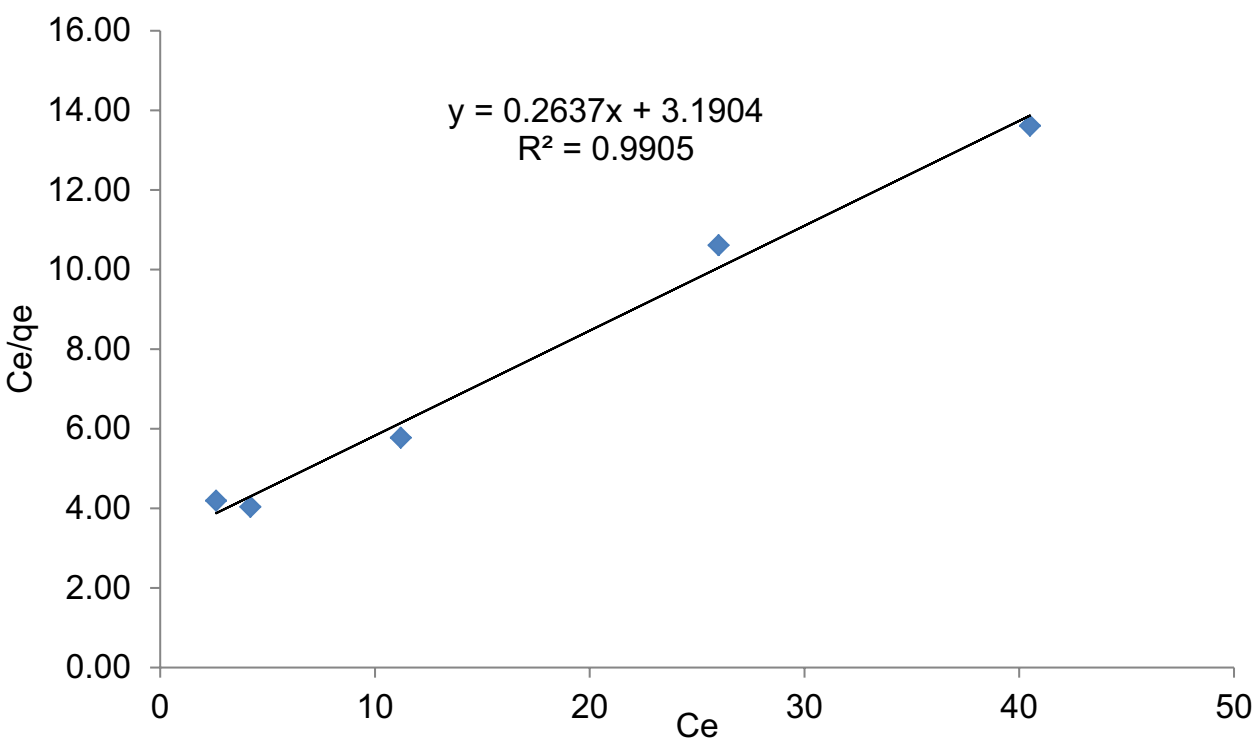

Table 1 Langmuir, Freundlich and Temkin isotherm constants for the adsorption of $\mathrm{Cr}(\mathrm{VI})$ ion unto groundnut shell

\begin{tabular}{llc}
\hline Model & Parameter & Value \\
\hline Langmuir & $q_{\mathrm{m}}$ & 3.792 \\
& $K_{\mathrm{L}}$ & 0.083 \\
& $R_{\mathrm{L}}$ & 0.243 \\
& $R^{2}$ & 0.9905 \\
Freundlich & $K_{\mathrm{F}}$ & 0.433 \\
& $n$ & 1.840 \\
& $\frac{1}{n}$ & 0.54 \\
Temkin & $R^{2}$ & 0.9535 \\
& $A$ & 1.028 \\
& $b$ & 3139.34 \\
& $B$ & 0.833 \\
& $R^{2}$ & 0.9944 \\
\hline
\end{tabular}

is an indicative of cooperative adsorption (Haghseresht and Lu 1998; Brasquet et al. 1997).

The Freundlich adsorption isotherm also conforms to the sorption of $\mathrm{Cr}(\mathrm{VI})$ ion from aqueous solutions using groundnut shell as shown in Fig. 8.

However, the level of conformity is to a less extent compared to the Langmuir adsorption isotherm as indicated by a lower correlation coefficient value of 0.9535 . From Table 1 , the value of $n$ (1.840) confirms that the groundnut shell have a heterogeneous surface since the value satisfy the heterogeneity condition, $1<n<10$. Also, a value of $\frac{1}{n}(0.54)$ below unity implies a chemisorption process (Haghseresht and $\mathrm{Lu}$ 1998; Brasquet et al. 1997). The values of $K_{\mathrm{F}}$ were found to be $0.433 \mathrm{mg} / \mathrm{g}$ which implies that there was low uptake of the metal ions unto the adsorbent surface.
The Temkin adsorption isotherm model is expressed as in Eq. (8):

$q_{\mathrm{e}}=\frac{\mathrm{RT}}{b} \ln A+\frac{\mathrm{RT}}{b} \ln C_{\mathrm{e}}$

Equation (7) can also be expressed as in equation (2.32)

$q_{\mathrm{e}}=B \ln A+B \ln C_{\mathrm{e}}$

where

$B=\frac{\mathrm{RT}}{b}$

$R$ is gas constant $(8.314 \mathrm{~J} / \mathrm{mol} / \mathrm{K}), T$ is temperature $(\mathrm{K})$, $C_{\mathrm{e}}$ is the concentration of solute in the bulk solution at equilibrium $(\mathrm{mg} / \mathrm{L}) ; q_{\mathrm{e}}$ is the corresponding adsorption capacity (mg/g), $b$ and $A$ are Temkin's constants. By plotting $q_{\mathrm{e}}$ versus $\ln C_{\mathrm{e}}$ (Fig. 9), the constant $b$ can be obtained from the slope, $\frac{\mathrm{RT}}{b}$ and $A$ from the intercept, $\frac{\mathrm{RT}}{b} \ln A$.

From Fig. 9, the correlation coefficient $\left(R^{2}\right)$ for the Temkin isotherm is 0.9944 which is higher than the values obtained from the other isotherm models. Hence, the experimental data fit very well to this isotherm model and indicate that $\mathrm{Cr}(\mathrm{VI})$ adsorption occurs because of the heat of adsorption $\left(\Delta H^{\circ}\right)$ of all molecules in the layer decreases linearly because of increased surface coverage (Aharoni and Ungarish 1977a, b). From Table 1, the intensity of sorption, A $(1.03 \mathrm{~L} / \mathrm{mg})$ and the heat of sorption $b$ ( $3139.34 \mathrm{~J} / \mathrm{mol}$ ) confirm further that the data best fit the Temkin isotherm. Hutson and Yang (1997) applied the Temkin isotherm model to confirm that the adsorption of cadmium ion unto nonzero-valent iron particles follows a chemisorption process. 
Fig. 8 Freundlich adsorption isotherm plot of $\mathrm{Cr}(\mathrm{VI})$ ion

Fig. 9 Temkin adsorption isotherm plot of $\mathrm{Cr}(\mathrm{VI})$ ion
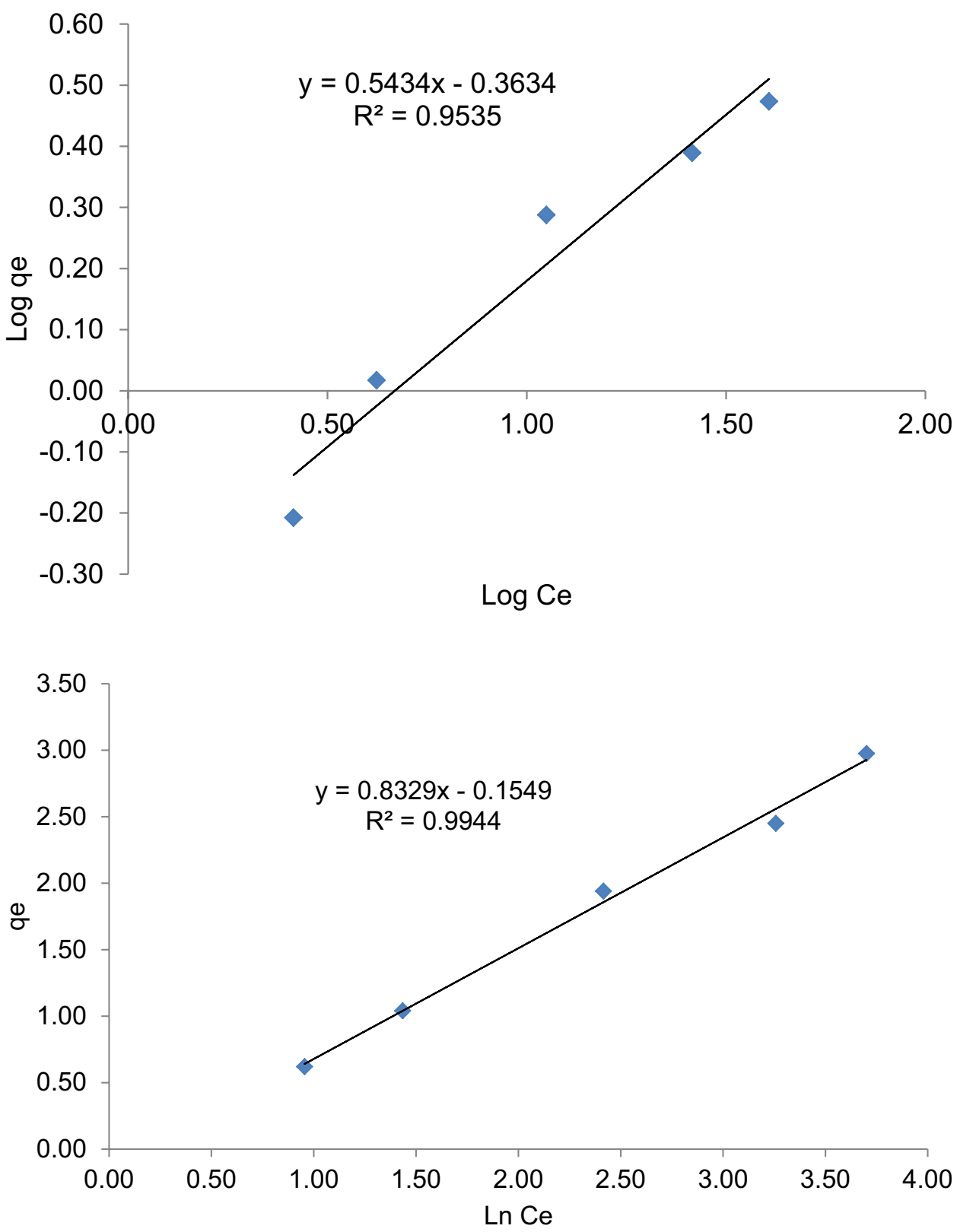

\section{Conclusion}

The groundnut shells investigated in this study exhibited high potential for the removal of chromium(VI) ion from aqueous solution even without physical or chemical modification. The adsorption of chromium(VI) ion was highly dependent on contact time, $\mathrm{pH}$, adsorbent dose, initial metal ion concentration and temperature. The adsorption of $\mathrm{Cr}(\mathrm{VI})$ was found to be optimum at a contact time of $120 \mathrm{~min}$; $\mathrm{pH}$ 8 ; adsorbent dose of $2.0 \mathrm{~g} / \mathrm{L}$; metal ion concentration of $25 \mathrm{mg} / \mathrm{L}$; and temperature of $41.5^{\circ} \mathrm{C}$. For all the isotherm models tested, Temkin model was found to have the highest correlation coefficient $\left(R^{2}\right)$ and hence the best fit.
Acknowledgements The authors appreciate the effort of the management of the University for Development Studies for equipping the Applied Chemistry and Biochemistry laboratory for core teaching and research work where this research work was carried out.

\section{Compliance with ethical standards}

Conflict of interest The authors report no conflict of interest.

Open Access This article is distributed under the terms of the Creative Commons Attribution 4.0 International License (http://creativeco mmons.org/licenses/by/4.0/), which permits unrestricted use, distribution, and reproduction in any medium, provided you give appropriate credit to the original author(s) and the source, provide a link to the Creative Commons license, and indicate if changes were made. 


\section{References}

Abdel-Tawwab M, El-Sayed GO, Shady SHH (2017) The capability of some agricultural wastes for removing some heavy metals from polluted water stocked in combination with Nile tilapia, Oreochromis niloticus (L.). Int Aquat Res 1:1. https://doi.org/10.1007/ s40071-017-0166-1

Aharoni C, Ungarish M (1977a) Kinetics of activated chemisorption. Part 2 - theoretical models. J Chem Soc Faraday Trans 1 Phys Chem Condens Phases 73(1):456. https://doi.org/10.1039/f19777300456

Aharoni C, Ungarish M (1977b) Kinetics of activated chemisorption. Part 2. Theoretical models. J Chem Soc, Faraday Trans 73:456-464

Ahmet Ö, Özer D, Özer A (2004) The adsorption of copper(II) ions on to dehydrated wheat bran (DWB): determination of the equilibrium and thermodynamic parameters. Process Biochem 39(12):2183-2191. https://doi.org/10.1016/j.procbio.2003.11.008

Aksu Z (2002) Determination of equilibrium, kinetic and thermodynamic parameters of batch biosorption of nickel(II) ions onto Chlorella vulgaris. Process Biochem 38:89-99

Alao O, Ajaelu C, Ayeni O (2014) Kinetics, equilibrium and thermodynamic studies of the adsorption of zinc(II) ions on Caria papaya root powder. Res J Chem Sci 4:32-38

APHA (1989) APHA-standard method for the examination of water and wastewater. American Water Works Association and Water Pollution; Control Federation, Washington, DC

Brasquet C, Subrenat E, Cloirec P (1997) Selective adsorption on fibrous activated carbon of organics from aqueous solution: correlation between adsorption and molecular structure. Water Sci Technol 35(7):251-259

Chakravarty P, Sarma NS, Sarma HP (2010) Removal of lead(II) from aqueous solution using heartwood of Areca catecha powder. Desalination 256:16-21

Chigondo F, Nyamunda B (2013) Removal of lead(II) and copper(II) ions from aqueous solution by baobab (Adansonia digitata) fruit shells biomass. IOSR J Appl Chem (IOSR-JAC) 5(1):43-50

Choudhury TR, Pathan KM, Amin N, Ali M, Quraishi SB (2012) Adsorption of $\mathrm{Cr}$ (III) from aqueous solution by groundnut shell. J Sci Water Resour 1(July):144-150

Eccles H (1999) Treatment of metal-contaminated wastes: why select a biological process? Trends Biotechnol 17:462-465

Edokpayi JN, Odiyo JO, Msagati TAM, Popoola EO (2015) A novel approach for the removal of lead(II) ion from wastewater using mucilaginous leaves of Diceriocaryum eriocarpum plant. Sustainability (Switzerland) 7(10):14026-14041. https://doi.org/10.3390/ su71014026

El-Ashtoukhy E-SZ, Amin NK, Abdelwahab O (2008) Removal of lead(II) and copper(II) from aqueous solution using pomegranate peel as a new adsorbent. Desalination 223(1-3):162-173. https:// doi.org/10.1016/j.desal.2007.01.206

Futalan CM, Tsai WC, Lin SS, Hsien KJ, Dalida ML, Wan MW (2012) Copper, nickel and lead adsorption from aqueous solution using chitosan-immobilized on bentonite in ternary system. Sustain Environ Res 22(6):345-355

García-Sánchez A, Álvarez-Ayuso E (2002) Sorption of Zn, Cd, and $\mathrm{Cr}$ on calcite. Application to purification of industrial wastewaters. Miner Eng 15(7):539-547. https://doi.org/10.1016/S0892 $-6875(02) 00072-9$

Haghseresht F, Lu G (1998) Adsorption characteristics of phenolic compounds onto coal-reject-derived adsorbents. Energy Fuels 12:1100-1107

Ho Y (2006) Isotherms for the sorption of lead onto peat: comparison of linear and non-linear methods. Pol J Environ Stud 15(1):81-86

Hutson ND, Yang RT (1997) The theoretical basis for the DubininRadushkevitch (D-R) adsorption isotherm equation. Adsorption 3(3):189-195. https://doi.org/10.1007/BF01650130
Idris S, Iyaka YA, Dauda BEN, Ndamitso MM, Umar MT (2012) Kinetic study of utilizing groundnut shell as an adsorbent in removing chromium and nickel from dye effluent. Am Chem Sci J 2(1):12-24. https://doi.org/10.9734/acsj/2012/908

Igwe JC, Abia AA (2006) A bioseparation process for removing heavy metals from waste water using biosorbents. Afr J Biotechnol 5(12):1167-1179

Krika F, Azzouz N, Ncibi MC (2016) Adsorptive removal of cadmium from aqueous solution by cork biomass: equilibrium, dynamic and thermodynamic studies. Arab J Chem 9:S1077-S1083. https://doi. org/10.1016/j.arabjc.2011.12.013

Kumar K, Sivanesan S (2007) Sorption isotherm for safranin onto rice husk: comparison of linear and non-linear methods. Dyes Pigments 72:130-133

Li X, Tang Y, Cao X, Lu D, Luo F, Shao W (2008) Preparation and evaluation of orange peel cellulose adsorbents for effective removal of cadmium, zinc, cobalt, and nickel. Colloids Surf A 317(1-3):512-521. https://doi.org/10.1016/j.colsurfa.2007.11.031

Lim SF, Lee AYW (2015) Kinetic study on removal of heavy metal ions from aqueous solution by using soil. Environ Sci Pollut Res 1:10. https://doi.org/10.1007/s11356-015-4203-6

Mahajan G, Sud D (2012) Modified agricultural waste biomass with enhanced responsive properties for metal-ion remediation: a green approach. Appl Water Sci 2(4):299-308. https://doi.org/10.1007/ s13201-012-0050-5

Meunier N, Drogui P, Montane C, Hausier R, Mercier G, Blais JF (2006) Comparison between electro coagulation and chemical precipitation for metal from acidic soil leachate. J. Hazard Mater B 137:581-590

Mohanty K, Jha M, Meikap BC, Biswas MN (2005) Removal of chromium(VI) from dilute aqueous solutions by activated carbon developed from Terminalia arjuna nuts activated with zinc chloride. Chem Eng Sci 60(11):3049-3059

Mohapatra M, Mohapatra L, Singh P, Anand S, Mishra BK (2010) A comparative study on $\mathrm{Pb}(\mathrm{II}), \mathrm{Cd}(\mathrm{II}), \mathrm{Cu}(\mathrm{II}), \mathrm{Co}(\mathrm{II})$ adsorption from single and binary aqueous solutions on additive assisted nano-structured goethite. Int J Eng Sci Technol 2(8):89-103. https ://doi.org/10.4314/ijest.v2i8.63784

Oluwamukomi M (2009) Adsorption isotherm modeling of soy-melonenriched and un-enriched 'gari' using gab equation. Afr J Food Sci 3(5):117-124

Onundi YB, Mamun AA, Al Khatib MF, Ahmed YM (2010) Adsorption of copper, nickel and lead ions from synthetic semiconductor industrial wastewater by palm shell activated carbon. Int J Environ Sci Technol. https://doi.org/10.1007/BF03326184

Park S, Jung WY (2001) Removal of chromium by activated carbon fibers plated with copper metal. Carbon Sci 2(1):15-21

Qaiser S, Saleemi AR, Umar M (2009) Biosorption of lead(II) and chromium(VI) on groundnut hull: equilibrium, kinetics, and thermodynamic study. Electron J Biotechnol. https://doi.org/10.2225/ vol12-issue4-fulltext-6

Rahmani K, Mahvi AH, Vaezi F et al (2009) Bioremoval of lead by use of waste activated sludge. Int J Environ Sci Technol 3(3):471-476

Rengaraj S, Kim Y, Joo CK, Choi K, Yi J (2004) Batch adsorptive removal of copper ions in aqueous solutions by ion exchange resins: $1200 \mathrm{H}$ and IRN97H. Korean J Chem Eng 21(3):187-194

Shah BA, Shah AV, Singh RR (2009) Sorption isotherms and kinetics of chromium uptake from wastewater using natural sorbent material. Int J Environ Sci Technol 6(1):77-90

Wan Ngah WS, Hanafiah MAKM (2008) Removal of heavy metal ions from wastewater by chemically modified plant wastes as adsorbents: a review. Biores Technol 99(10):3935-3948. https://doi. org/10.1016/j.biortech.2007.06.011

Wu D, Niu C, Li D, Bai Y (2004) Solvent extraction of scandium(III), yttrium(III), lanthanum(III) and gadolinium(III) using Cyanex 
302 in heptane from hydrochloric acid solutions. J Alloys Compd 374:442-446. https://doi.org/10.1016/j.jallcom.2003.11.058

Wuana RA, Okieimen FE (2011) Heavy metals in contaminated soils: a review of sources, chemistry, risks and best available strategies for remediation. ISRN Ecol 2011:1-20. https://doi. org/10.5402/2011/402647

Xunjun C (2015) Modeling of experimental adsorption isotherm data. Information (Switzerland) 6(1):14-22. https://doi.org/10.3390/ info6010014

Yusuff AS (2018) Optimization of adsorption of $\mathrm{Cr}(\mathrm{VI})$ from aqueous solution by Leucaena leucocephala seed shell activated carbon using the design of the experiment. Appl Water Sci 8(8):1-11. https://doi.org/10.1007/s13201-018-0850-3

Publisher's Note Springer Nature remains neutral with regard to jurisdictional claims in published maps and institutional affiliations. 